\title{
PENGARUH LATAR BELAKANG PENDIDIKAN, PENGALAMAN, PELATIHAN DAN HUBUNGAN ANTAR KARYAWAN TERHADAP KINERJA MANTRI PADA PT BANK RAKYAT INDONESIA (PERSERO) TBK CABANG SAMUDERA BANJARMASIN
}

\author{
Muhammad Teguh Nuryadin, Riswan Yunida, Shinta Febiyansari \\ Program Studi Administrasi Bisnis \\ Politeknik Negeri Banjarmasin \\ Jl. Brigjen hasan Basri Kayutangi ( Komplek Unlam) Banjarmasin 70123 \\ E-mail: teguhnuryadin@ poliban.ac.id, riswan@poliban.ac.id, shintakhaiyan@gmail.com
}

\begin{abstract}
The purpose of this study was to determine the effect of educational background, experience, training and the relationship between employees on the performance of paramedics. The research method used is a quantitative method. Data collection techniques are questionnaires, observations, and interviews. The data analysis technique used is multiple linear regression data analysis techniques using SPSS for Windows software. And as many as 86 respondents. The results of this study indicate that (1) the variables of educational background, experience, training, and relations between employees have a simultaneous effect on the performance of paramedics at PT Bank Rakyat Indonesia (Persero) Tbk, Samudera Banjarmasin Branch with aFcalculated $=4,449$ and a significant value of 0.003 ,(2) variable educational background does not affect the partial value(t-calc $<$ ttable $=1,155<1,663)$, the variable does not affect the partial experiences with the value $(t$-calc $<$ ttable $=-0009<1,663)$, training has no effect significantly with the value $(t$ calc $<$ ttable $=0.149<1,663)$, while the relationship variable between employees has a partial effect with the value $(t$-calc $>$ ttable $=3.167>1,663)$, and $(3)$ the most dominant variable is the relationship variable between employees with tcount $=3,167$.
\end{abstract}

Keywords: Background of Education, Training, Experience, Inter-employee Relations, Multiple Linear Regression

\begin{abstract}
Abstrak
Tujuan penelitian ini untuk mengetahui pengaruh latar belakang pendidikan, pengalaman, pelatihan dan hubungan antar karyawan terhadap kinerja mantri. Metode penelitian yang digunakan adalah metode kuantitatif. Teknik pengumpulan data yaitu kuesioner, observasi, dan wawancara. Teknik analisis data yang digunakan adalah teknik analisis data regresi linier berganda menggunakan software SPSS for windows. Serta responden sebanyak 86 orang. Hasil penelitian ini menunjukkan bahwa (1) variabel latar belakang pendidikan, pengalaman, pelatihan, dan hubungan antar karyawan berpengaruh secara simultan terhadap kinerja mantri pada PT Bank Rakyat Indonesia (Persero) Tbk, Cabang Samudera Banjarmasin dengan nilai $\mathrm{F}_{\text {hitung }}=4.449$ dan nilai signifikan 0.003,(2) variabel latar belakang pendidikan tidak berpengaruh secara parsial dengan nilai $\left(\mathrm{t}_{\text {hitung }}<\mathrm{t}_{\text {tabel }}=1.155<\right.$ 1.663), variabel pengalaman tidak berpengaruh secara parsial dengan nilai $\left(\mathrm{t}_{\text {hitung }}<\mathrm{t}_{\text {tabel }}=-0.009<\right.$ 1.663), pelatihan tidak berpengaruh secara signifikan dengan nilai $\left(\mathrm{t}_{\text {hitung }}<\mathrm{t}_{\text {tabel }}=0.149<1.663\right)$, sedangkan variabel hubungan antar karyawan berpengaruh secara parsial dengan nilai $\left(\mathrm{t}_{\text {hitung }}>\mathrm{t}_{\text {tabel }}=\right.$ $3.167>1.663$ ), dan (3) variabel yang berpengaruh paling dominan adalah variabel hubungan antar karyawan dengan $t_{\text {hitung }}=3.167$.
\end{abstract}

Kata kunci: Latar Belakang Pendidikan, Pelatihan, Pengalaman, Hubungan Antar karyawan, Regresi Linier Berganda. 


\section{PENDAHULUAN}

Dalam penyaluran dana dalam bentuk kredit ini dilakukan oleh seorang credit officer atau mantri, mantri pada kenyataannya merupakan ujung tombak bank dalam memasarkan suatu produk, pihak bank harus memiliki strategi khusus agar dapat memaksimalkan keuntungan.

Dalam bahan ajar (account officer, 2009) pihak bank memiliki dua strategi yaitu pertama strategi menyerang yaitu bersikap agresif dalam menjerat calon nasabah, agresif maksudnya adalah memiliki persiapan matang dalam melakukan kegiatan promosi yang bahwa Bank Rakyat Indonesia memiliki produk dan fasilitas pelayanan yang terbaik, kedua strategi bertahan yaitu mempertahankan standar produk dan fasilitas yang ada dan berusaha menambah atau meningkatkan. Berikut adalah data mantri Bank Rakyat Indonesia pada enam belas unit di Banjarmasin:

Tabel 1. Latar Belakang Pendidikan Mantri Pada PT Bank Rakyat Indonesia (Persero) Tbk Cabang Samudera Banjarmasin

\begin{tabular}{|l|c|}
\hline $\begin{array}{c}\text { Latar Belakang } \\
\text { Pendidikan }\end{array}$ & Jumlah \\
\hline Ekonomi & 29 \\
\hline Manajemen & 19 \\
\hline Hukum & 3 \\
\hline Teknik & 13 \\
\hline Sosial & 3 \\
\hline Psikologi & 1 \\
\hline Pendidikan & 18 \\
\hline Total & 86 \\
\hline
\end{tabular}

Sumber :PT Bank Rakyat Indonesia (Persero) Tbk Cabang Samudera Banjarmasin (2018)

Tabel 1 diatas merupakan data latar belakang pendidikan mantri. Dapat dilihat bahwa tidak semua pegawai mantri pada Bank Rakyat Indonesia dengan latar belakang pendidikan ekonomi tetapi juga dengan latar belakang pendidikan lain.

Berdasarkan uraian di atas, penulis tertarik untuk melakukan penelitian dengan judul "Pengaruh Latar Belakang Pendidikan, Pengalaman, Pelatihan dan Hubungan Antar karyawan Pada PT Bank Rakyat Indonesia (Persero) Tbk Cabang Samudera Banjarmasin".

\section{Indentifikasi Penelitian}

Identifikasi masalah dalam penelitian ini adalah ;

Apakah terdapat pengaruh secara simultan antara variabel latar belakang pendidikan, pengalaman, pelatihan, dan hubungan antar karyawan terhadap kinerja mantri pada PT Bank Rakyat Indonesia (Persero),Tbk Cabang Samudera Banjarmasin?

Dan Apakah terdapat pengaruh secara parsial antara variabel latar belakang pendidikan, pengalaman, pelatihan, dan hubungan antar karyawan terhadap kinerja mantri pada PT Bank Rakyat Indonesia (Persero),Tbk Cabang Samudera Banjarmasin?,

Serta Apakah terdapat variabel yang paling dominan dari variabel latar belakang pendidikan, pengalaman, pelatihan, dan hubungan antar karyawan terhadap kinerja mantri pada PT Bank Rakyat Indonesia (Persero), Tbk Cabang Samudera Banjarmasin?

\section{Tujuan dan Manfaat Penelitian}

Tujuan dari penelitian ini adalah Untuk mengetahui pengaruh secara simultan antara variabel latar belakang pendidikan, pengalaman, pelatihan, dan hubungan antar karyawan terhadap kinerja mantri pada PT Bank Rakyat Indonesia (Persero), Tbk Cabang Samudera Banjarmasin dan Untuk mengetahui pengaruh secara parsial antara 
variabel latar belakang pendidikan, pengalaman, pelatihan, dan hubungan antar karyawan terhadap kinerja mantri pada PT Bank Rakyat Indonesia (Persero), Tbk Cabang Samudera Banjalirmasin Serta untuk mengetahui variabel yang paling dominan dari variabel latar belakang pendidikan, pengalaman, pelatihan, dan hubungan antar karyawan terhadap kinerja mantri pada PT Bank Rakyat Indonesia (Persero), Tbk Cabang Samudera Banjarmasin.

\section{Manfaat Penelitian}

Secara teoritis manfaat penelitian diharapkan dapat memberikan bahan referensi kepada peneliti selanjutnya terutama berkenaan dengan pengaruh latar belakang pendidikan, pengalaman, pelatihan, dan hubungan antar karyawan terhadap kinerja mantri pada bank.

Secara praktis manfaat penelitian diharapkan dapat dijadikan pertimbangan untuk mengetahui pengaruh latar belakang pendidikan, pengalaman, pelatihan, dan hubungan antar karyawan terhadap kinerja mantri pada PT Bank Rakyat Indonesia (Persero), Tbk Cabang Samudera Banjarmasin.

\section{TINJAUAN PUSTAKA}

\section{Manajemen Sumber Daya Manusia}

Menurut (Gary Dessler, 2010:4) manajemen sumber daya manusia sebagai kebijakan dan latihan untuk memenuhi kebutuhan karyawan atau aspek-aspek yang terdapat dalam sumber daya manusia seperti posisi manajemen, pengadaan karyawan atau rekrutmen, penyaringan, pelatihan, kompensasi, dan penilaian prestasi kerja karyawan.

Manajemen sumber daya manusia adalah suatu ilmu dan seni yang digunakan untuk mengatur orang atau karyawan, mengembangkan potensi manusia dan organisasinya, untuk melakukan serangkaian proses perencanaan, pengorganisasian, pengarahan dan pengawasan terhadap pengadaan, pemeliharaan, sampai pemberhentian sebagai upaya-upaya untuk mengembangkan aktivitas manusia dalam mencapai tujuan organisasi secara efektif dan efisien.

\section{Latar Belakang Pendidikan}

(Sudarsono, 2001:74; dalam Anik Mulyawati, 2008:4) kualifikasi pekerja yang dibutuhkan untuk memangku suatu jabatan seperti pendidikan, pengalaman, keterampilan yang harus dimiliki. Dengan semakin tinggi tingkat pendidikan seorang karyawan maka dia akan memiliki pengetahuan dan wawasan yang luas.

\section{Pengalaman Kerja}

Nitisemito, 2000:65; dalam Rofi, 2012) mengemukakan bahwa pengalaman kerja adalah lamanya seorang karyawan mengabdi pada perusahaan tertentu pekerjaan yang optimal bergantung pada kemampuan, kecakapan dan ketrampilan.

\section{Pelatihan}

(Handoko, 2001:101 dalam Citra Indah Zuana, dkk, 2014:3) mengemukakan bahwa pelatihan dalam sebuah perusahaan untuk meningkatkan pengetahuan kerja seorang karyawan dalam bidang kreativitas dan tata cara pelaksanaan kerja tertentu.

\section{Hubungan Antar karyawan}

(Citra Indah Zuana, 2013; dalam Iqbal Maulana, 2016:1) menyatakan karyawan maupun karyawati merupakan sumber dayaa manusia bagi perusahaan atau organisasi, dalam pencapaian tujuan dan penyelesaian tugas-tugas perusahaan organisasi ataupun perusahaan tidak dapat lepas dari peranan karyawan maupun karyawati perusahaan. 
(Citra Indah Zuana, 2013; dalam Iqbal Maulana, 2016:2) mengungkapkan karyawan yang mampu menyelesaikan kegiatan dengan baik sehingga dapat mencapai hasil yang sangat optimal, apabila lingkungan kerja seorang karyawan dapat menunjang pada hasil kerja tersebut.

\section{Kinerja}

Menurut (Hasibuan, 2010:10) kinerja merupakan perwujudan kerja yang dilakukan oleh karyawan yang biasanya dipakai sebagai dasar penilaian terhadap karyawan atau organisasi.

Berdasarkan Penjelasan di atas, maka hipotesis penelitian ini dapat dirumuskan sebagai berikut:

H1 : Diduga bahwa terdapat pengaruh secara simutan antara latar belakang pendidikan, pengalaman, pelatihan, dan hubungan antar karyawan terhadap kinerja mantri pada Bank Rakyat Indonesia (Persero) Tbk, Cabang Samudera Banjarmasin.

H2 : Diduga bahwa terdapat pengaruh secara parsial latar belakang pendidikan, pengalaman, pelatihan, dan hubungan antar karyawan terhadap kinerja mantri pada PT Bank Rakyat Indonesia (Persero) Tbk, Cabang Samudera Banjarmasin.

H3 : Diduga bahwa terdapat variabel yang paling dominan antara latar belakang pendidikan, pengalaman, pelatihan, dan hubungan antar karyawan terhadap kinerja mantri pada PT Bank Rakyat Indonesia (Persero) Tbk, Cabang Samudera Banjarmasin.

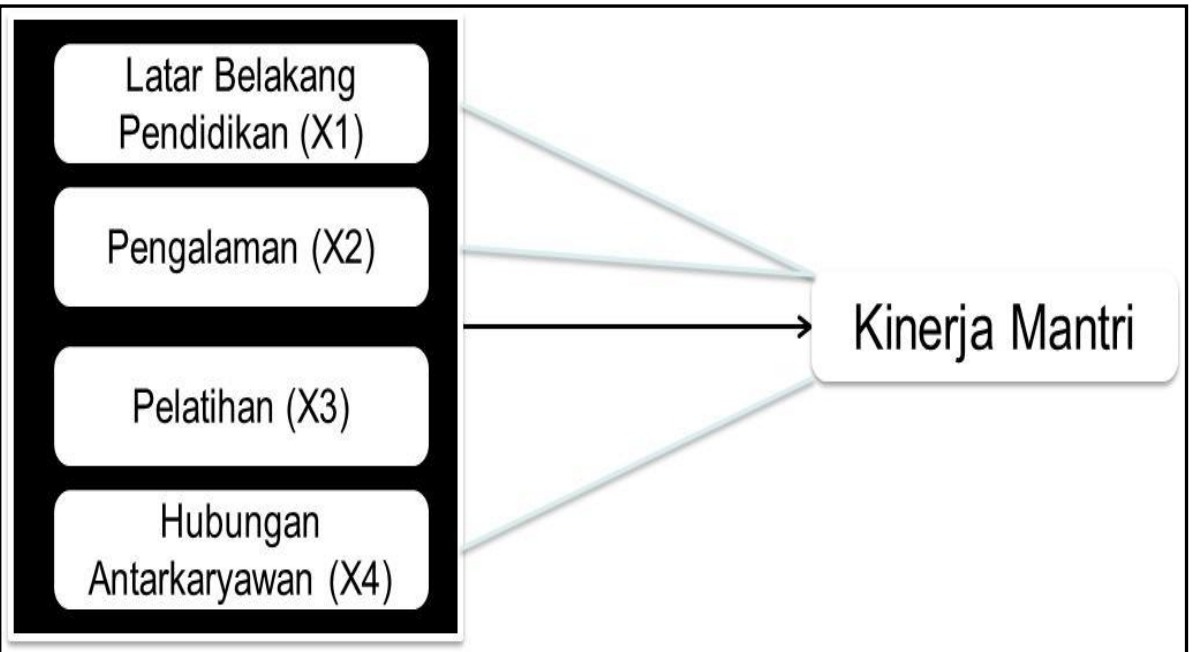

Gambar 1. Model Kerangka Berpikir

\section{METODE PENELITIAN}

\section{Jenis Penelitian}

Penelitian ini menggunakan jenis penelitian kuantitatif dengan tujuan untuk melihat pengaruh latar belakang pendidikan; pengalaman kerja; pelatihan; dan hubungan antar karyawan terhadap kinerja mantri.

Lokasi dan waktu Penelitian
Lokasi dalam penelitian ini adalah unit dari PT Bank Rakyat Indonesia (Persero) Tbk Cabang Samudera Banjarmasin.

Populasi dan Ukuran Sampel Penelitian

Sampel dalam penelitian ini adalah seluruh populasi staf mantri pada PT Bank Rakyat Indonesia (Persero) Tbk Cabang Samudera Banjarmasin yang berjumlah 86 
orang. Berdasarkan jumlah yang ada, seluruh populasi dijadikan sampel. Teknik pengambilan data dalam penelitian ini menggunakan metode Sampling Jenuh (Sensus), yaitu teknik penentuan sampel bila semua anggota populasi digunakan sebagai sampel.

\section{Teknik Pengumpulan Data}

Teknik Pengumpulan data dalam penelitian ini dengan melakukan pengisian kuesioner dari responden atau sampel yang sudah ditentukan sebelumnya, serta melakukan wawancara dan observasi langsung pada objek peneltian agar informasi didapat secara maksimal dan objektif.

\section{Metode Analisis Data}

Metode penelitian ini adalah deskriptif kuantitatif ddengan menggunakan pendekatan statistic dari hasil kuesioner yang telah didapat dan diolah menggunakan regresi linier berganda.

\section{HASIL DAN PEMBAHASAN}

\section{Hipotesis Pertama}

Berdasarkan tabel 2, dapat diketahui nilai $F_{\text {hitung }}$ sebesar 4,449 $>F_{\text {tabel }}$ 2,48 dengan nilai signifikansi sebesar $0,003<0,05$. Sehingga dapat disimpulkan bahwa latar belakang pendidikan, pengalaman, pelatihan dan hubungan antar karyawan berpengaruh secara simultan terhadap kinerja mantri pada PT Bank Rakyat Indonesia (Persero) Tbk Cabang Samudera Banjarmasin.

\section{Hipotesis Kedua}

Berdasarkan tabel 3, variabel latar belakang pendidikan diperoleh nilai thitung sebesar $(1,155)<t_{\text {tabel }}(1,663)$. maka Ho diterima dan Ha ditolak. Sehingga dapat disimpulkan bahwa secara parsial variabel latar belakang pendidikan tidak berpengaruh signifikan terhadap kinerja mantri pada PT
Bank Rakyat Indonesia Cabang Samudera Banjarmasin

Sedangkan nilai $\mathrm{r}^{2}$ variabel citra pembuat sebesar 0,016 atau $1,6 \%$ jadi secara statistik dimensi ini masih memberikan kontribusi walaupun sangat kecil.

Berdasarkan tabel 3, variabel pegalaman diperoleh nilai thitung sebesar $(-0,009)<t_{\text {tabel }}$ $(1,663)$. maka Ho diterima dan Ha ditolak. Sehingga dapat disimpulkan bahwa secara parsial variabel pengalaman tidak berpengaruh signifikan terhadap kinerja mantri pada PT Bank Rakyat Indonesia Cabang Samudera Banjarmasin

Sedangkan nilai $\mathrm{r}^{2}$ variabel citra pembuat sebesar 0,000.

Berdasarkan tabel 3, variabel pelatihan diperoleh nilai thitung sebesar $(0,149)<t_{\text {tabel }}$ (1,663). maka Ho diterima dan Ha ditolak. Sehingga dapat disimpulkan bahwa secara parsial variabel pelatihan tidak berpengaruh signifikan terhadap kinerja mantri pada PT Bank Rakyat Indonesia Cabang Samudera Banjarmasin

Sedangkan nilai $\mathrm{r}^{2}$ variabel citra pembuat sebesar 0,000.

Berdasarkan tabel 3, variabel hubungan antar karyawan diperoleh nilai thitung sebesar $(3,167)>t_{\text {tabel }}(1,663)$. maka Ho ditolak dan Ha diterima. Sehingga dapat disimpulkan bahwa secara parsial variabel hubungan antar karyawan berpengaruh signifikan terhadap kinerja mantri pada PT Bank Rakyat Indonesia Cabang Samudera Banjarmasin

Sedangkan nilai $r^{2}$ variabel citra pembuat sebesar 0,110 atau $11 \%$ jadi secara statistik dimensi ini masih memberikan kontribusi terhadap kinerja mantri pada PT Bank Rakyat Indonesia Cabang Samudera Banjarmasin. 
Hipotesis Ketiga

Berdasarkan tabel 3, dapat diketahui bahwa nilai $\mathrm{r}^{2}$ yang paling besar terdapat pada variabel hubungan antar karyawan yaitu sebesar 0,110 atau $11 \%$ sehingga dapat disimpulkan variabel yang berpengaruh paling dominan adalah variabel hubungan antar karyawan.

Tabel 2. Hasil Pengujian Hipotesis

\begin{tabular}{|c|c|c|c|c|c|c|}
\hline $\begin{array}{l}\text { Variabel } \\
\text { Terikat }\end{array}$ & Variabel Bebas & $\begin{array}{c}\text { Koefisien } \\
\text { Regresi }\end{array}$ & $\begin{array}{c}\text { t } \\
\text { hitun } \\
\text { g }\end{array}$ & Sig & $\begin{array}{c}\mathrm{r} \\
\text { partia } \\
\mathbf{l}\end{array}$ & $\begin{array}{c}r \\
\text { partia } \\
l^{2}\end{array}$ \\
\hline \multirow{4}{*}{$\begin{array}{l}\text { Kinerja } \\
\text { Mantri } \\
\text { (Y) }\end{array}$} & $\begin{array}{l}\text { Latar belakang } \\
\text { pendidikan (X1) }\end{array}$ & 0.113 & 1.155 & $\begin{array}{l}0.2 \\
52 \\
\end{array}$ & 0.127 & .016 \\
\hline & Pengalaman (X2) & -0.001 & $\begin{array}{c}- \\
0.009 \\
\end{array}$ & $\begin{array}{l}0.9 \\
93 \\
\end{array}$ & 0.000 & .000 \\
\hline & Pelatihan (X3) & 0.022 & 0.149 & $\begin{array}{l}0.8 \\
82\end{array}$ & 0.017 & .000 \\
\hline & $\begin{array}{c}\text { Hubungan Antar } \\
\text { Karyawan (X4) }\end{array}$ & 0.416 & 3.167 & $\begin{array}{l}0.0 \\
02\end{array}$ & 0.332 & .110 \\
\hline \multicolumn{3}{|c|}{$\begin{array}{l}\text { Konstanta : } 5.579 \\
\mathrm{R}: 0.424 \\
\text { R Square : } 0.180 \\
\text { Adjusted R Square : } 0.140\end{array}$} & \multicolumn{4}{|c|}{$\begin{array}{l}\mathrm{F}_{\text {hitung }}: 4.449 \\
\text { Sig } \mathrm{F}: 0.003 \\
\mathrm{~F}_{\text {tabel }}: 2.48 \\
\mathrm{~T}_{\text {tabel }}: 1.663 \\
\text { SEE: } 1.455\end{array}$} \\
\hline
\end{tabular}

Sumber: Data diolah (2018)

Tabel 3. Rangkumen Nilai $t_{\text {hitung }}$ dan $t_{\text {tabel }}$

\begin{tabular}{|c|c|c|c|c|c|c|c|}
\hline $\begin{array}{c}\text { Variabel } \\
\text { Bebas }\end{array}$ & $\mathbf{t}_{\text {hitung }}$ & Sig & $\mathbf{t}_{\text {tabel }}$ & Keterangan & $\mathbf{r}_{\text {parsial }}$ & $\begin{array}{c}\mathbf{r} \\
\text { parsial }^{2}\end{array}$ & $\begin{array}{c}\text { Signifikan } \\
\text { atau tidak }\end{array}$ \\
\hline $\begin{array}{c}\mathrm{X}_{1}: \\
\text { Latar } \\
\text { belakang } \\
\text { pendidikan }\end{array}$ & 1.155 & 0.252 & 1.663 & $\mathrm{t}_{\text {hitung }}<\mathrm{t}_{\text {tabel }}$ & 0.127 & 0.016 & $\begin{array}{c}\text { Tidak } \\
\text { Signifikan }\end{array}$ \\
\hline $\begin{array}{c}\mathrm{X}_{2}: \\
\text { Pengalaman }\end{array}$ & -0.009 & 0.993 & 1.663 & $\mathrm{t}_{\text {hitung }}<\mathrm{t}_{\text {tabel }}$ & 0.000 & 0.000 & $\begin{array}{c}\text { Tidak } \\
\text { Signifikan }\end{array}$ \\
\hline $\begin{array}{c}\mathrm{X}_{3}: \\
\text { Pelatihan }\end{array}$ & 0.149 & 0.882 & 1.663 & $\mathrm{t}_{\text {hitung }}<\mathrm{t}_{\text {tabel }}$ & 0.017 & 0.000 & $\begin{array}{c}\text { Tidak } \\
\text { Signifikan }\end{array}$ \\
\hline $\begin{array}{c}\mathrm{X}_{4}: \\
\text { Hubungan } \\
\text { Antar } \\
\text { Karyawan }\end{array}$ & 3.167 & 0.002 & 1.663 & $\mathrm{t}_{\text {hitung }}>\mathrm{t}_{\text {tabel }}$ & 0.332 & 0.110 & Signifikan \\
\hline
\end{tabular}

Sumber: Data diolah (2018)

\section{KESIMPULAN DAN SARAN}

\section{Kesimpulan}

Berdasarkan hasil pembahasan pada bab-bab sebelumnya, dapat ditarik kesimpulan bahwa:
Latar belakang pendidikan, pengalaman, pelatihan, dan hubungan antar karyawan berpengaruh secara simultan terhadap kinerja mantri pada PT Bank Rakyat Indonesia (Persero) Tbk, Cabang Samudera Banjarmasin. 
Latar belakang pendidikan, pengalaman, pelatihan tidak berpengaruh secara parsial terhadap kinerja mantri, sedangkan hubungan antar karyawan berpengaruh secara parsial terhadap kinerja mantri pada PT Bank Rakyat Indonesia (Persero) Tbk, Cabang Samudera Banjarmasin.

Variabel hubungan antar karyawan merupakan variabel yang paling dominan dalam mempengaruhi kinerja mantri pada PT Bank Rakyat Indonesia (Persero) Tbk, Cabang Samudera Banjarmasin.

\section{Saran}

Sehubungan dengan kesimpulan di atas, dapat dikemukakan saran-saran sebagai berikut:

Sebaiknya PT Bank Rakyat Indonesia (Persero) Tbk, Cabang Samudera Banjarmasin perlu memperhatikan latar belakang pendidikan, pengalaman, pelatihan, dan hubungan antar karyawan terhadap mantri, karena hal tersebut berpengaruh secara simultan terhadap kinerja mantri.

Sebaiknya PT Bank Rakyat Indonesia (Persero) Tbk, Cabang Samudera Banjarmasin perlu memperhatikan hubungan antar karyawan terhadap mantri, karena hal tersebut berpengaruh secara parsial terhadap kinerja mantri.

Sebaiknya PT Bank Rakyat Indonesia (Persero) Tbk, Cabang Samudera Banjarmasin perlu memperhatikan variabel hubungan antar karyawan, karena hal tersebut merupakan variabel yang paling dominan dalam mempengaruhi kinerja mantri.

\section{Keterbatasan}

Keterbatasan dalam penelitian ini adalah tidak dapat menggambarkan informasi sepenuhnya mengenai latar belakang pendidikan yang sesuai dengan jenis pekerjaan mantri, karena efektifitas kerja mantri dapat tertutupi dan di capai dengan terjalinnya hubungan antar karyawan yang erat pada objek penelitian ini.

\section{DAFTAR PUSTAKA}

Adibah, Ayuk Wahdanfiari. 2014. "Pengaruh Latar Belakang Pendidikan dan Pengalaman Kerja terhadap Etos Kerja Karyawan Bank BNI Syariah Kantor Cabang Kediri". Tulungagung: Fakultas Ekonomi dan Bisnis Islam Institut Agama Islam Negeri Tulungagung.

Ahmad, Nur dan Didik Hermawan. 2012. "Analisis Pengaruh Hubungan Karyawan (Employee Relation) terhadap Kepuasan Kerja Karyawan PT Menara Kartika Buana". Surakarta: Fakultas Ekonomi Universitas Muhammadiyah Surakarta.

Bernardin, H. Jhon dan Russel. 1998. Pelatihan dan Pengembangan Untuk Meningkatkan Kinerja SDM. Bandung: ALFABETA.

Dessler, Gary. 2004. Manajemen Sumber Daya Manusia. Jakarta: Indeks.

Farida. 2016. "Pengaruh Latar Belakang Pendidikan dan Pelatihan terhadap Produktivitas Kerja Karyawan pada PT Latrade Batam Indonesia". Batam: Akuntansi Permata Harapan Batam.

Ghozali, Imam. 2005. Aplikasi Analisis Multivirate dengan SPSS. Semarang: Badan Penerbit UNDIP.

Gujarati, Damodar. 2005. Ekonometrika Dasar. Jakarta: Erlangga.

Handoko, T. Hani. 2001. Manajemen Personalia dan Sumber Daya Manusia. Yogyakarta: BPFE

Hasibuan, Malayu S.P. 2011. Manajemen Sumber Daya Manusia. Jakarta: Bumi Aksara.

Husein, Umar. 2005. Metode Penelitian. Jakarta. Salemba Empat.

Kasmir, 2014. Bank dan Lembaga Keuangan Lainnya edisi Revisi 2014. Jakarta: Rajawali Pers. 
Mangkunegara, Anwar Prabu. 2009. Manajemen Sumber Daya Manusia Perusahaan. Bandung: Remaja Rosdakarya.

Mathis, Robert L. dan John H. Jackson. 2006. Human Resource Management. Jakarta: Salemba Empat.

Maulana, Iqbal. 2016. "Tingkat Produktivitas Kerja Karyawan terhadap Kinerja Karyawan Account Officer (AO) Bank BRI (Bank Rakyat Indonesia) Cabang Pamekasan Madura”. Surabaya: Sekolah Tinggi Ilmu Ekonomi Perbanas Surabaya.

Mulyawati, Anik. 2008 "Pengaruh pendidikan dan pengalaman kerja terhadap motivasi kerja karyawan dibagian Spinning pada PT Hanil Indonesia. FKIP Muhammadiyah Surakarta.

Nitisemito, Alex S. 1986. Manajemen Personalia. Jakarta: Ghalia Indonesia.
Santoso, Singgih. 2004. Statistik Multivariat dan Nonparametrik. Jakarta: PT Elex Media Komputindo.

Sri, Dini Ega. 2013. "Pengaruh Latar Belakang Pendidikan dan Pelatihan terhadap Kinerja Account Officer (Ao) Kredit Komersial Bank Bri Sumatera Barat”. Padang: STKIP PGRI Sumatera Barat.

Sugiyono, 2008. Metode Penelitian Pendidikan. Bandung: ALFABETA.

Tim Penyusun. 2018. "Buku Pedoman Penulisan Laporan PKL dan Tugas Akhir". Banjarmasin: Jurusan Administrasi Bisnis Politeknik Negeri Banjarmasin.

Yogi, I Kadek. 2015. "Pengaruh Latar Belakang Pendidikan dan Pengalaman Kerja terhadap Kinerja Karyawan pada PT Federal International Finance (FIF) Group Cabang Singaraja”. Singaraja: Universitas Pendidikan Ganesha Singaraja. 